\title{
Antimicrobial Resistance in Bacterial Isolates Recovered from Nursing Hospitals between 2014 and 2017
}

\author{
Seon Han Yun ${ }^{1,2 *}$, Bareum Gwon ${ }^{2,3 *}$, Hea Lim Hong', Hwan Seop Lim ${ }^{1}$, Kyung Ryul Lee ${ }^{1}$, \\ Inho Jang ${ }^{2}$, Eun-Jeong Yoon ${ }^{3}$, Seok Hoon Jeong ${ }^{3}$ \\ ${ }^{1}$ Seoul Clinical Laboratory, Seoul, ${ }^{2}$ Department of Clnical Pathology, Sangii University College of Science, \\ Wonju, ${ }^{3}$ Department of Laboratory Medicine and Research Institute of Bacterial Resistance, \\ Yonsei University College of Medicine, Seoul, Korea
}

Background: Antimicrobial resistance (AMR) is an issue not only with regard to public health, but also in terms of economic impact. AMR surveillance has mainly been carried out in general hospitals, and not in nursing hospitals. This study was conducted to investigate the AMR rate for bacterial strains isolated from nursing hospital samples.

Methods: Antimicrobial susceptibility testing (AST) results from a total of 23,518 bacterial isolates recovered from clinical specimens taken in 61 nursing hosals were analyzed. AST was conducted using Vitek 2 with AST cards specific for the bacterial strains.

Results: A total of 19,357 Gram-negative and 4,161 Gram-positive bacterial strains were isolated. Pseudomonas aeruginosa $(n=6,384)$ and Escherichia coli $(n=$ 5,468 ) were the most prevalent bacterial species and, among Gram-positive bacteria, Staphylococcus aureus $(n=1,565)$ was common. The AMR rate was high for the following strains: cefotaxime-resistant Klebsiella pneumoniae, $77.4 \%$; cefotaxime-resistant $E$. coli, 70.6\%; imipenem-resistant Acinetobacter baumannii, $90.3 \%$; imipenem-resistant $P$. aeruginosa, $49.3 \%$; oxacillin-resistant $S$. aureus, $81.1 \%$, penicillin-resistant Enterococcus faecalis, $44.8 \%$, and vancomycin-resistant Enterococcus faecium, $53.5 \%$. AMR rate change varied by bacterial species and antimicrobial drug.

Conclusion: AMR rates of major pathogens from nursing hospitals were higher than those from general hospitals with the exception of imipenem-resistant $A$. baumannii. Continuous monitoring and infection control strategies are needed. (Ann Clin Microbiol 2019;22:96-104)

Key Words: Antimicrobial resistance, Nursing hospital, Surveillance study

\section{INTRODUCTION}

항균제 내성 세균에 의한 환자 감염은 치료 항균제 범위의 제한으로 치료 실패, 환자의 입원기간 연장 및 의료비용 증가 를 유발하기 때문에, 내성 세균의 확산은 공중보건 및 사회경 제적으로 심각한 문제이다[1]. 이 때문에 항균제 내성 세균의 발생은 국가적 차원에서 감시되고 관리되고 있을 뿐 아니라[2], 세계보건기구(World Health Organization, WHO) 주도로 전세 계적인 감시 또한 이루어지고 있다[3]. 우리나라의 항균제 내성 감시는 종합병원에서 분리한 세균을 중심으로 질병관리본부 주관 하에 이루어져 왔다. 전국의 종합병원에서 해당 연도의 일정기간에 수집한 주요 균종에 대한 항균제 감수성 시험 결과 를 수집하여 분석하는 항균제내성모니터링시스템(Korean Antimi- crobial Resistance Monitoring System, KARMS)을 2002년부터 2015년까지 실시하였고[4], 2016년 5월부터는 WHO에서 제안 한 Global Antimicrobial Resistance Surveillance System (GLASS) 의 감시체계 디자인을 우리나라의 상황에 적용하여, 종합병원 에서 수집한 혈액, 요, 분변, 요도 및 자궁경부 검체에서 분리한 주요 세균 전수를 수집하여 감수성시험을 실시하고 분석하는 Kor-GLASS가 시행중이다[5].

요양병원에서 발생하는 감염병의 원인세균 내성률은 비교적 높은 것으로 알려져 있으며[6], 전문적인 치료, 추적관찰과 감 염관리가 필요한 주요 내성세균 감염도 흔하게 발견되는 것으 로 알려져 있다[7,8]. 항균제 내성 세균은 조밀한 입원실에 입 원한 면역력이 약한 입원환자 사이 혹은 입원환자와 의료진 사 이의 접촉[9], 환자의 전원[10], 의료진의 이동[11] 등에 의해

Received 7 May, 2019, Revised 7 June, 2019, Accepted 7 June, 2019

Correspondence: Eun-Jeong Yoon, Department of Laboratory Medicine and Research Institute of Bacterial Resistance, Yonsei University College of Medicine, 211 Eonju-ro, Gangnam-gu, Seoul 06273, Korea. (Tel) 82-2-2019-3783, (Fax) 82-2-2019-3784, (E-mail) ejyoon@yuhs.ac *Both contributed equally as a first author.

(C) The Korean Society of Clinical Microbiology.

() This is an Open Access article distributed under the terms of the Creative Commons Attribution Non-Commercial License (http://creativecommons.org/licenses/by-nc/4.0) which permits unrestricted non-commercial use, distribution, and reproduction in any medium, provided the original work is properly cited. 
전파되는 것으로 파악되며, 이는 종합병원에서 일어나는 원내 감염의 경우와 유사하다[8,9]. 만성질환을 가진 입원환자를 대 상으로 하는 요양병원의 특성때문에, 급성기병원에서 감염증 의 치료를 위하여 항균제 투여를 받다가 전원하여 입원하는 경 우가 많고, 병증이 악화되어 종합병원 등의 급성기병원으로 다 시 전원되는 경우가 다반사이다[12]. 환자의 전원으로 인한 병 원간 항균제 내성균 전이의 예는 흔하며[13,14], 이는 요양병원 과 종합병원 간의 경우도 예외가 아니다[15]. 즉, 요양병원의 높은 항균제 내성률은 요양병원에만 국한된 문제로 치부할 수 없고, 공공의료 전반에 영향을 미칠 수 있는 문제이다. 전문인 력 수급 및 비용 등의 문제로 인하여 요양병원의 감염관리는 적절한 수준에 도달하지 못하였으며, 급성기 의료기관을 기준 으로 마련된 감염관리 지침을 준용한 자발적 감염관리에 의존 하고 있는 실정이다[16]. 정부에서도 이러한 문제를 인지하고 있으며, 지난 2018년 6월 질병관리본부에서 발표한 의료관련 감염 예방관리 종합대책에서 요양병원을 포함한 중소병원에 대한 감염관리 활동에 대한 보상체계 마련 등을 통하여 개선하 겠다는 의지를 표명한 바 있다[17].

인구 고령화의 영향으로 요양병원이 늘어나고 있으며, 요양 병원의 항균제 내성 세균 확산은 환자의 상태에 따라 수시로 상호 전원이 발생하는 종합병원의 감염관리에도 문제를 일으 키고 있다. 요양병원의 항균제 내성 현황을 근거로 대응책이 마련되어야 하나, 국내에는 아직 체계적인 감시체계가 미비한 상태이다. 이에 본 연구에서는 전국에 지점을 가지고 있는 한 수탁기관의 최근 4년간 항균제 감수성 시험결과를 분석하여 요 양병원의 항균제 내성 현황을 파악하고자 하였다.

\section{MATERIALS AND METHODS}

\section{1. 검체 및 정보 수집}

총 14 개 지역에 29 개 지점을 가진 국내 일개 수탁기관에 의 뢰된 배양 및 항균제 감수성 시험 결과를 분석하였다. 2014년 1월부터 2017년 12월까지 4년간 연속 의뢰 이력이 있는 총 61 개 요양병원에서 의뢰한 검체에서 세균이 분리되고 항균제 감 수성 결과가 있는 23,518건이 본 연구에 포함되었으며, 4년간 의 연속 위탁 이력이 확인되지 아니한 기관의 데이터는 분석에 포함하지 않았다. 결과 분석에 포함된 권역별 요양병원의 수는 Fig. 1 과 같다. 가능한 경우, 환자의 성별과 나이에 관련한 정보 를 수집하였으나, 위탁기관에서 이에 대한 정보를 제공하지 않

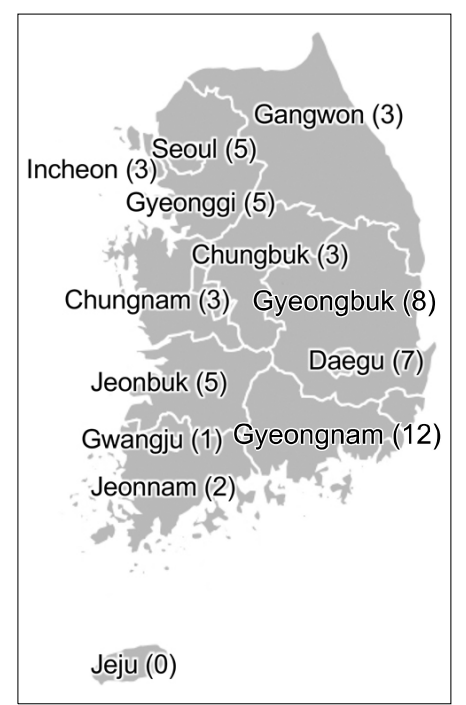

Fig. 1. Participating nursing hospitals in this study. Numbers of nursing hospitals are indicated in parentheses after the name of each district.

Table 1. Patients included in the study

\begin{tabular}{|c|c|c|c|c|}
\hline \multirow{2}{*}{ Species } & \multirow{2}{*}{ Total } & \multicolumn{3}{|c|}{ Sex } \\
\hline & & Male & Female & Unknown \\
\hline E. coli & $5,468(23.3 \%)$ & $1,129(27.8 \%)$ & $2,934(72.2 \%)$ & 1,405 \\
\hline K. pneumoniae & $3,346(14.2 \%)$ & $1,338(52.4 \%)$ & $1,216(47.6 \%)$ & 769 \\
\hline A. baumannii & $2,885(12.3 \%)$ & $1,433(63.8 \%)$ & $812(36.2 \%)$ & 640 \\
\hline P. aeruginosa & $6,384(27.1 \%)$ & $2,955(58.9 \%)$ & $2,061(41.1 \%)$ & 1,368 \\
\hline Other Gram-negatives* & $1,274(5.4 \%)$ & $574(57.1 \%)$ & $431(42.9 \%)$ & 269 \\
\hline S. aureus & $1,565(6.7 \%)$ & $650(49.6 \%)$ & $660(50.4 \%)$ & 255 \\
\hline E. faecalis & $564(2.4 \%)$ & $160(37.4 \%)$ & $268(62.6 \%)$ & 136 \\
\hline E. faecium & $776(3.3 \%)$ & $225(35.3 \%)$ & $413(64.7 \%)$ & 138 \\
\hline Other Gram-positives $^{\dagger}$ & $1,256(5.3 \%)$ & $530(50.3 \%)$ & $23(49.7 \%)$ & 203 \\
\hline Total & $23,518(100 \%)$ & $8,994(49.1 \%)$ & $9,318(50.9 \%)$ & 5,183 \\
\hline
\end{tabular}

*Other Gram-negatives include S. marcescense $(\mathrm{n}=641)$, Enterobacter spp. $(\mathrm{n}=319)$, and Citrobacter $\mathrm{spp} .(\mathrm{n}=314)$; ${ }^{\dagger}$ Other Gram-positive include coagulase-negative staphylocci ( $\mathrm{n}=972)$, S. agalatiae $(\mathrm{n}=160)$, and $S$. pneumoniae $(\mathrm{n}=124)$. 
은 경우가 있어 남, 여, 알 수 없음(unknown)의 세 가지로 구분 하여 분석하였다. 검체의 종류는 농양, 혈액, 호흡기, 요, 창상, 기타의 6 가지로 구분하였다.

\section{2. 균종 동정과 항균제 감수성 검사}

검체에서 분리된 세균은 VITEK 2 (bioMerieux, Marcyl'Étoile, France) 장비를 이용한 생화학적 방법 또는 Bruker Biotyper (Bruker Daltonics $\mathrm{GmbH}$, Bremen, Germany) 장비를 사용한 matrix assisted laser desorption ionization-time of flight mass spectrometry 법으로 동정하였다. 항균제 감수성은 VITEK 2 장비를 사용하여 시험하였다. 균종별로 사용한 감수 성 검사 카드로는, Escherichia coli, Klebsiella pneumonia, Enterobacter spp, Citrobacter spp, Serratia marcesces 등의 Enterobacteriaceae는 AST-N274 카드를, 비 발효성 균주인 Acinetobacter baumannii와 Pseudomonas aeruginoisa는 ASTN255 카드, staphylococci는 AST-P610 카드, enterococci는 AST-P600 카드, streptococci는 AST-ST01 카드를 사용하였다.

\section{RESULTS}

\section{1. 연도별 항균제 감수성 검사 의뢰 건수와 분리된 세균 균종}

연간 항균제 감수성 검사 의뢰되어 배양검사에서 양성이 확 인된 검체의 건수는 2014년 4,783건에서 매년 약 $29 \%$ 증가하 여 2017년에는 6,177건에 달하였다(Table 1). 그람음성세균의 분리비율이 그람양성세균에 비해 4.0배 높았다(19,357 : 4,161). 분리된 그람음성세균은 대부분이 E. coli $(28.2 \%, 5,468 / 19,357)$ 또는 P. aeruginosa $(33.0 \%, \mathrm{n}=6,384)$ 이었으며, K. pneumoniae (17.3\%, n=3,346), A. baumannii (14.9\%, $\mathrm{n}=2,885)$, S. marcescense
(3.3\%, n=641), Enterobacter spp. (1.6\%, n=319), Citrobacter spp. $(1.6 \%, \mathrm{n}=314)$ 가 그 뒤를 이었다. 그람양성세균 분리 균종은 S. aureus $(37.6 \%, 1,565 / 4,161)$ 와 E. faecalis $(16.2 \%, \mathrm{n}=674), E$. faecium $(16.0 \%, \mathrm{n}=666)$ 이 $70 \%$ 를 차지하였고 coagulase-negative staphylocci가 $19.9 \% \quad(\mathrm{n}=972)$, Str. agalatiae 가 $3.3 \%$ $(\mathrm{n}=160)$ S. pneumoniae가 2.5\% $(\mathrm{n}=124)$ 를 차지하였다. 특징적 으로, E. coli와 P. aeruginosa의 분리율이 전체의 절반을 차지했 다.

환자의 성별은, 균종별로 약간의 차이가 있었으나, $49.1 \%$ : $50.9 \%$ 로 남여의 비율이 거의 같았다(Table 1). E. coli와 E. faecalis, E. faecium 은 남여 비율이 $35: 65$ 에서 $30: 70$ 으로 여성 환자에서 더 많이 분리되는 양상을 보였고, A. baumannii와 $P$. aeruginosa는 $65: 35,60: 40$ 의 비율로 남성 환자에서 더 많이 분리되었다.

균종별로 흔하게 분리되는 검체의 종류가 상이하였다(Table 2). E. coli $(80.8 \%, 4,417 / 5,468)$ 와 E. faecalis $(81.9 \%, 462 / 564)$ 는 요검체에서의 분리비율이 $4 / 5$ 가량이었고, K. pneumoniae (63.5\%, 2,126/3,346), A. baumannii (76.8\%, 2,215/2,885), P. aeruginosa $(75.1 \%, 4,794 / 6,384)$ 는 호흡기검체에서의 분리비율 이 각 $3 / 4$ 가량이었다. S. aureus는 과반이 호흡기검체에서 분 리되었고(57.1\%,894/1,565), 창상검체에서 분리된 경우(17.2\%, $\mathrm{n}=269$ )가 그 뒤를 이었다. E. faecium는 과반이 요검체에서 $(57.6 \%, 447 / 776)$ 분리되었다.

\section{2. 주요 균종의 항균제 감수성}

총 7종의 주요 균종에 대한 항균제 감수성을 연도별로 분석 하였고, 그 중 주요내성세균의 분리율을 지역별로 분석하였다.

K. pneumpniae는 cefoxitin과 카바페넴을 제외한 전부의 베

Table 2. Specimens included in the study

\begin{tabular}{|c|c|c|c|c|c|c|c|}
\hline \multirow{2}{*}{ Species } & \multirow{2}{*}{ Total } & \multicolumn{6}{|c|}{ Specimens } \\
\hline & & Abscess & Blood & Respiratory & Urinary & Wound & Others \\
\hline E. coli & $5,468(23.3 \%)$ & $71(18.2 \%)$ & $358(20.0 \%)$ & $415(3.6 \%)$ & $4,417(54.1 \%)$ & $185(14.8 \%)$ & $22(5.7 \%)$ \\
\hline K. pneumoniae & $3,346(14.2 \%)$ & $30(7.7 \%)$ & $108(6.0 \%)$ & $2,126(18.5 \%)$ & $941(11.5 \%)$ & $100(8.0 \%)$ & $18(4.6 \%)$ \\
\hline A. baumannii & $2,885(12.3 \%)$ & $47(12.0 \%)$ & $47(2.6 \%)$ & $2,215(19.3 \%)$ & $302(3.7 \%)$ & $253(20.2 \%)$ & $21(5.4 \%)$ \\
\hline$P$. aeruginosa & $6,384(27.1 \%)$ & $88(22.5 \%)$ & $67(3.7 \%)$ & $4,794(41.7 \%)$ & $1,083(13.3 \%)$ & $327(26.1 \%)$ & $25(6.4 \%)$ \\
\hline $\begin{array}{l}\text { Other } \\
\text { Gram-negatives* }\end{array}$ & $1,274(5.4 \%)$ & $9(2.3 \%)$ & $39(2.2 \%)$ & $896(7.8 \%)$ & $273(3.3 \%)$ & $52(4.2 \%)$ & $5(1.3 \%)$ \\
\hline S. aureus & $1,565(6.7 \%)$ & $109(27.9 \%)$ & $179(10.0 \%)$ & $894(7.8 \%)$ & $101(1.2 \%)$ & $269(21.5 \%)$ & $13(3.4 \%)$ \\
\hline E. faecalis & $564(2.4 \%)$ & $3(0.5 \%)$ & $72(12.8 \%)$ & - & $462(81.9 \%)$ & $11(2.0 \%)$ & $16(2.8 \%)$ \\
\hline E. faecium & $776(3.3 \%)$ & - & $46(5.9 \%)$ & $4(0.5 \%)$ & $447(57.6 \%)$ & $19(2.4 \%)$ & $260(33.5 \%)$ \\
\hline $\begin{array}{l}\text { Other } \\
\text { Gram-positives }\end{array}$ & $1,256(5.3 \%)$ & $34(8.7 \%)$ & 877 (48.9\%) & $158(1.4 \%)$ & $143(1.8 \%)$ & $36(2.9 \%)$ & $8(2.1 \%)$ \\
\hline Total & 23,518 & 391 & 1,793 & 11,502 & 8,169 & 1,252 & 388 \\
\hline
\end{tabular}

*Other Gram-negatives include S. marcescense $(\mathrm{n}=641)$, Enterobacter spp. $(\mathrm{n}=319)$, and Citrobacter $\mathrm{spp} .(\mathrm{n}=314) ;{ }^{\dagger}$ Other Gram-positives include coagulase-negative staphylocci $(\mathrm{n}=972)$, S. agalatiae $(\mathrm{n}=160)$, and $S$. pneumoniae $(\mathrm{n}=124)$. 

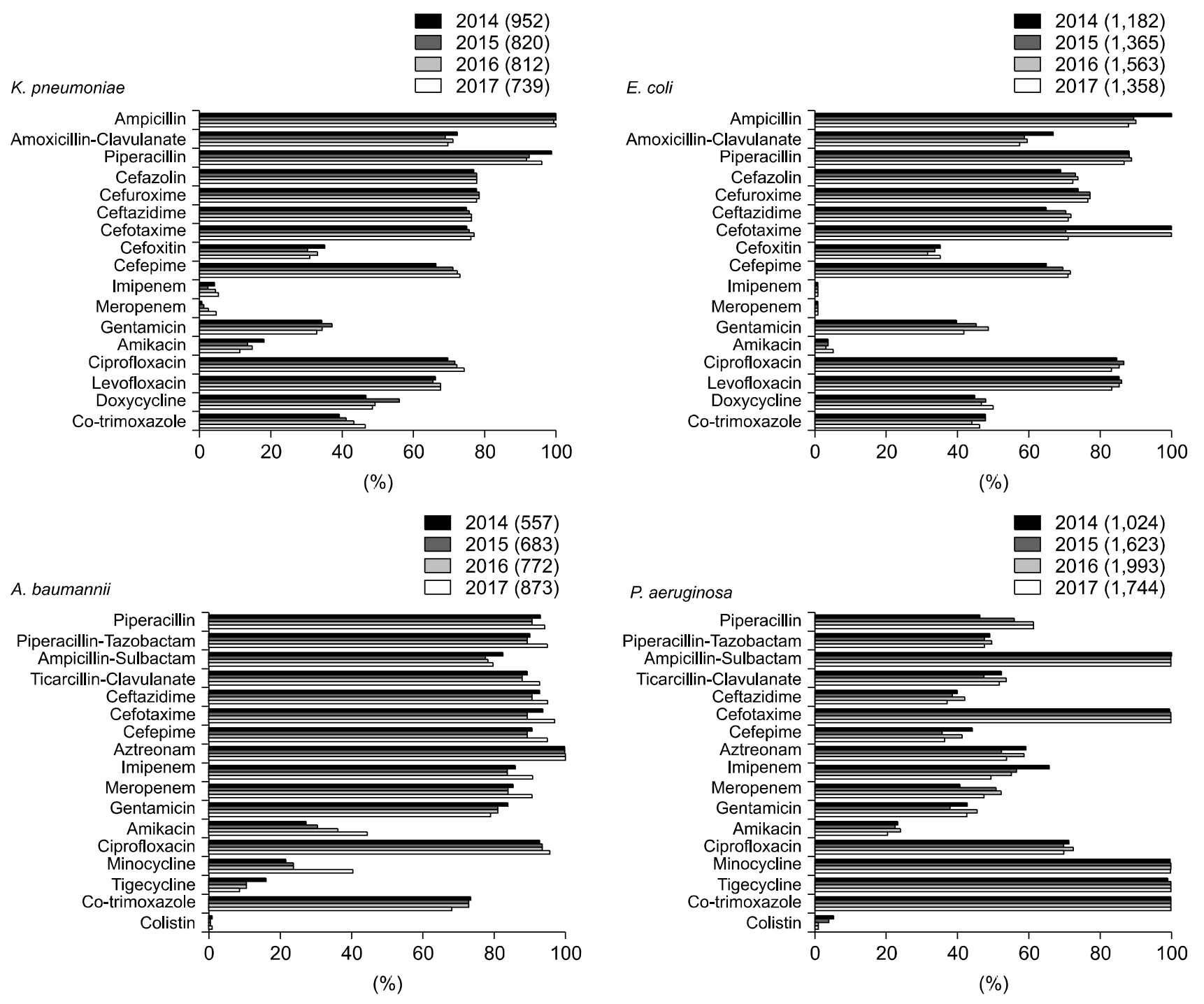

Fig. 2. Resistance rates of $K$. pneumoniae, E. coli, A. baumannii, and $P$. aeruginosa in each year. Each bar indicates resistance rate of the year: black bar for 2014, dark gray for 2015, light gray for 2016, and white for 2017. Numbers of isolates analyzed are presented in parentheses following the year in the plot legend.

타락탐 항균제에 대해 $70 \%$ 이상의 내성률을 보였다(Fig. 2). 그 중 piperacillin에 대한 내성률은 4년간 $10.9 \%$ 감소한 반면 (2014년 98.8\%에서 2017년 87.9\%), cefepime (2014년 66.1\%에 서 2017년 73.9\%)에 대한 내성률은 7.8\%, imipenem (2014년 4.2\%에서 2017년 8.0\%) 및 meropenem (2014년 0.9\%에서 2017 년 7.4\%)에 대한 내성률은 $3.8 \%, 6.5 \%$ 증가하였다. Gentamicin 에 대한 내성률은 amikacin에 대한 내성률보다 2 배 가량 높았 으나 공히 $40 \%$ 를 넘지 않았다. Ciprofloxacin에 대한 내성률은 2014년 69.9\%에서 2017년 75.0\%로 5.1\% 상승하였으나, levofloxacin은 $66.4 \%$ 에서 $68.0 \%$ 로 내성률 상승폭이 $1.6 \%$ 에 그쳤 다. 주요한 내성균으로 분류되는 cefotaxime 내성 K. pneumo$n i a e$ 의 경우, 지역별로 큰 차이없이 내성률이 높았다(Fig. 3). 4 년간, 충남지역을 제외한 전국에서 내성률이 유지되거나 늘어
나는 것을 확인할 수 있었다.

E. coli의 경우, 세팔로스포린 내성률이 2014년에서 2016년 까지 상승추세를 보이다가 2017년에 잠시 주춤하는 양상을 보 였다(Fig. 2). 가장 큰 내성률 변화폭은 ceftazidime (2014년 $64.9 \%, 2015$ 년 69.7\%, 2016년 71.4\%, 2017년 70.6\%)과 cefepime (2014년 64.7\%, 2015년 69.6\%, 2016년 71.4\%, 2017년 $70.6 \%$ )에서 확인되었다. 카바페넴 내성률은 4년간 공히 $1.0 \%$ 를 넘지 않았고, amikacin에 대한 내성률도 2017년에 보인 최 고치가 5.3\%였다. 플루오로퀴놀론 내성은 연도별 큰 차이 없이 $84 \%$ 수준이었다. E. coli의 cefotaxmie 내성은 2014년과 2016 년에 공히 $100 \%, 2015$ 년과 2017 년에는 각 $69.9 \%$ 과 $70.6 \%$ 로, 격년의 편차를 확인할 수 있었는데, 지역별 차이는 거의 찾아 볼 수 없었다는 것이 특징적이었다(Fig. 3). 


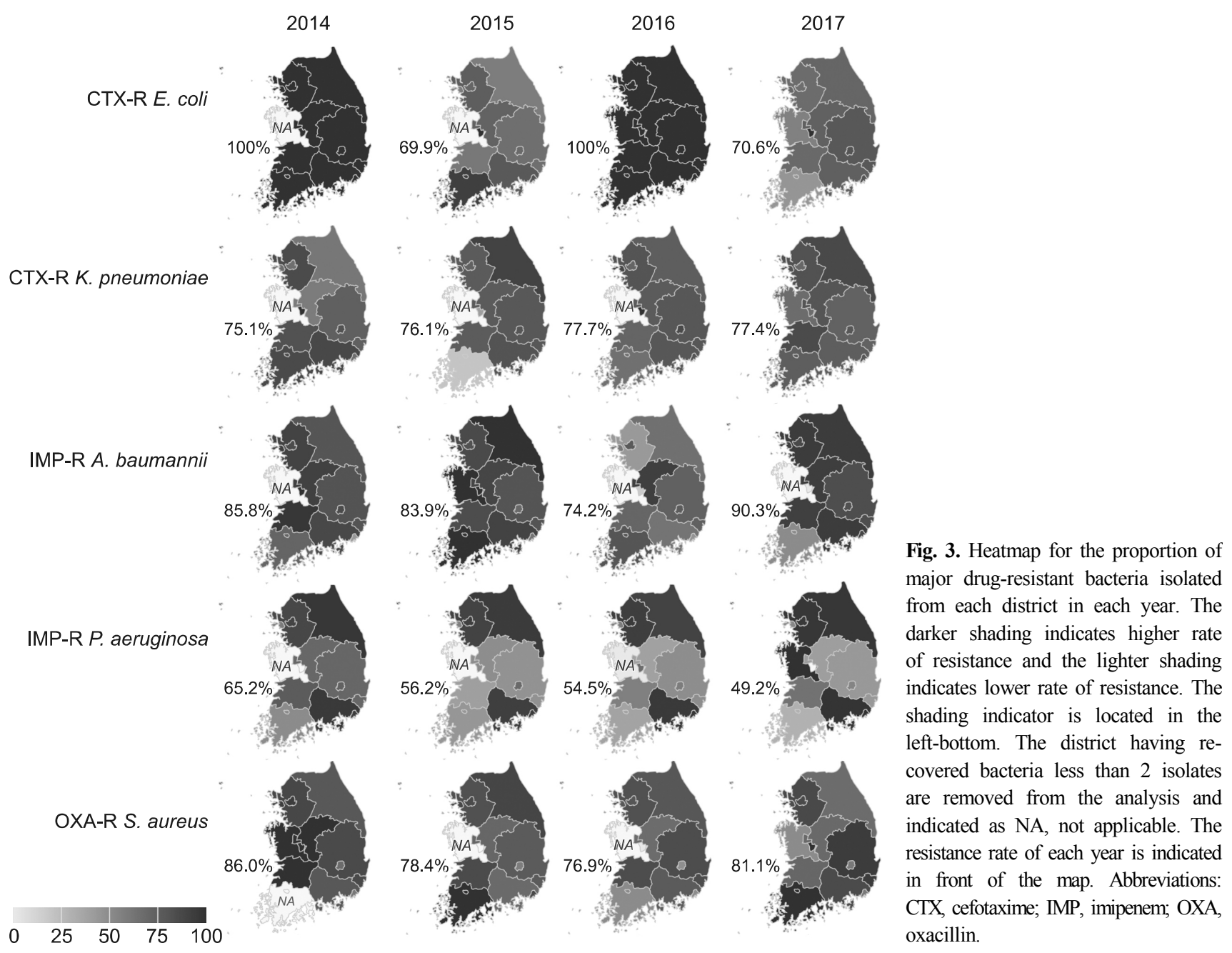

A. baumannii는 4년간 내성률 상승추세를 보이는 amikacin (2014년 27.5\%, 2015년 30.9\%, 2016년 36.3\%, 2017년 44.6\%) 과 감소추세를 보이는 tigecycline (2014년 15.9\%, 2015년 11.0\%, 2016년 11.0\%, 2017년 8.3\%), co-trimoxazole (2014년 $73.1 \%, 2015$ 년 72.6\%, 2016년 72.6\%, 2017년 67.7\%)을 제외하 고는 연도별 변화 없이 전반적으로 높은 내성률을 보였다(Fig. 2). Aztreonam에 대한 내성률이 특징적으로 매우 높아 $99.5 \%$ 에서 $100 \%$ 에 달하였다. Imipenem에 대한 내성률은 2014년 85.8\%, 2015년 83.9\%, 2016년 74.2\%이던 것이 2017년에 90.3\%로 급 격히 상승하였으며, 경기권에 소재한 요양병원에서 분리한 균 주의 급격한 내성률 변화가 반영된 것으로 확인되었다(Fig. 3).

P. aeruginosa의 경우, 4년간 큰 변화 없이 ampicillin-sulbactam, cefotaxime, minocycline, tigecycline, co-trimoxazole에 대한 내 성률이 $98.5 \%$ 에서 $100 \%$ 로 매우 높았다(Fig. 2). 특징적으로, piperacillin에 대한 내성률은 증가추세를 (2014년 45.8\%, 2015 년 56.0\%, 2016년 61.5\%, 2017년 61.2\%) 보였고, imipenem에 대한 내성률은 감소추세를 (2014년 65.3\%, 2015년 56.3\%, 2016년 54.7\%, 2017년 49.3\%) 보였다. 지역별로, 충청 이북과
경남지역의 imipenem 내성률은 변화가 없거나 오히려 늘어나 는 추세였으나, 충청과 그 이남 지역의 내성률이 감소하여 전 체적인 감소패턴이 나타난 것으로 확인되었다(Fig. 3).

S. aureus의 oxacillin 내성률과 ciprofloxacin 내성률은 2014 년부터 2016년까지 감소하다가 2017년에 다시 상승하였다 (Fig. 4). Erythromycin (2014년 68.6\%, 2015년 62.9\%, 2016년 $60.1 \%, 2017$ 년 59.1\%)과 clindamycin에 대한 내성률(2014년 $65.7 \%, 2015$ 년 57.1\%, 2016년 54.1\%, 2017년 51.0\%)은 4년간 일정한 감소추세를 보였으며, quinupristin/dalfopristin 내성균은 4년간 한차례도 검출되지 않았다. 이와 더불어, linezolid, vancomycin, teicoplanin 내성균도 검출된 바 없었다. Mupirocin에 대한 내성률은 2014년에 $14.8 \%$ 이던 것이 2015년에 $17.9 \%$, 2016년에 $18.1 \%$, 2017년에 21.3\%로 매년 증가추세를 보였다. 사용한 Vitek 2 AST-P610 카드에서는, cefoxitin대신 oxacillin 을 methicillin-resistant $S$. aureus (MRSA)의 마커로 사용하고 있어, oxacillin 내성을 토대로 MRSA의 발생률을 추정할 수밖 에 없었다. 서울과 수도권 지역의 oxacillin 내성 S. aurues 발생 률 차이는 거의 없었으나, 충청지역과 이남의 내성률에 연도별 


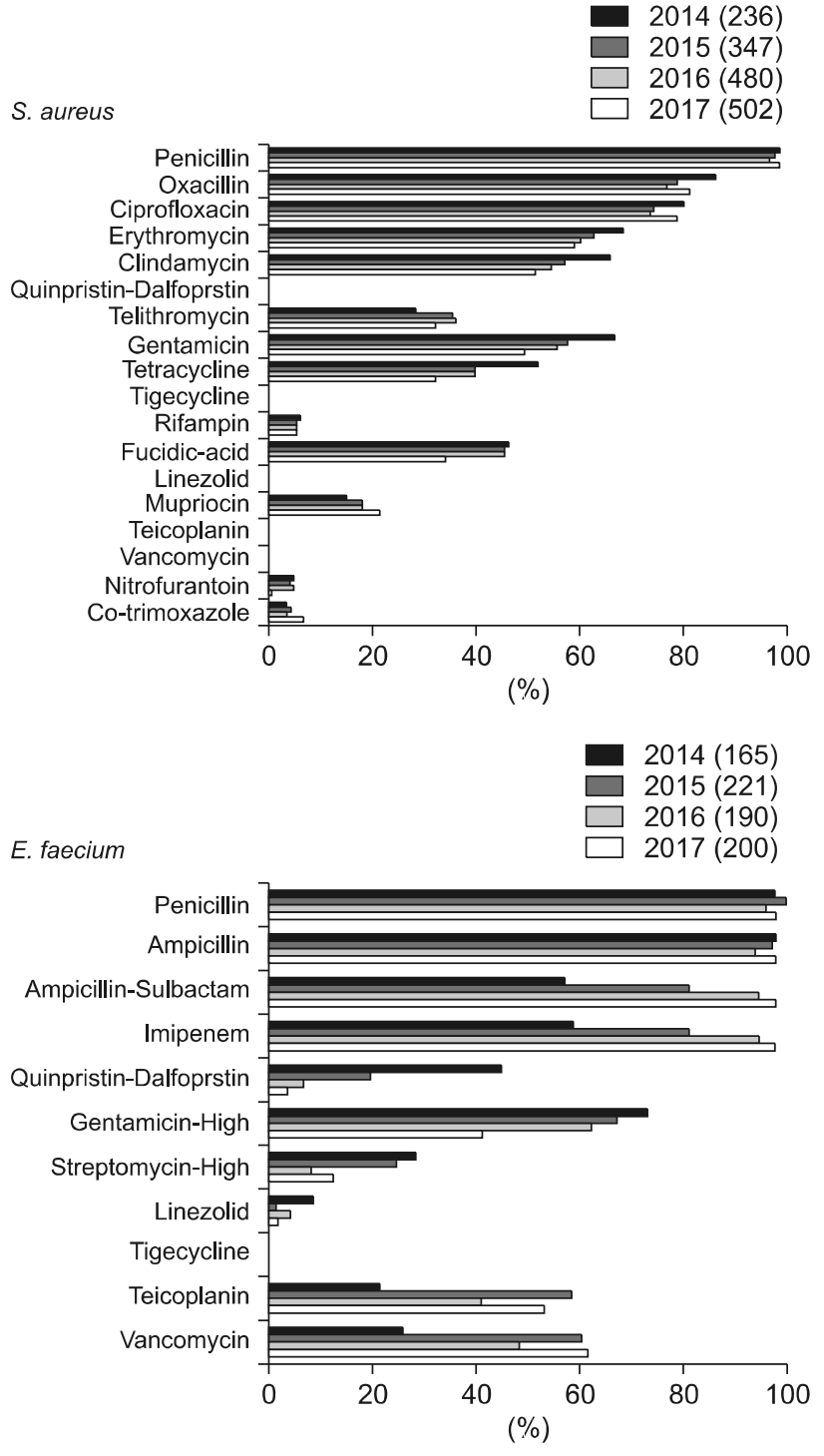

차이가 있어 연간 발생률에 영향을 미친 것으로 확인되었다 (2014년 86.0\%, 2015년 78.4\%, 2016년 76.9\%, 2017년 81.8\%) (Fig. 3).

E. faecalis 는 ampicillin, ampicillin-sulbactam, tigecycline 내 성주는 4년의 연구기간중 검출되지 않았다. Penicillin에 대한 내성률이 4년간 눈에 띄게 증가하여 2014년에 3.4\%이던 것이 2015년에 38.4\%, 2016년에 43.9\%로 늘어, 2017년에는 44.8\% 가 되었다(Fig. 4). Quinupristin/dalfopristin에 대해서는 4년 내 내 $98.2 \%$ 에서 $100 \%$ 사이의 높은 내성률을 보였다. Vancomycin과 teicoplanin에 대한 내성은 공히 2014년에 확인되지 않았 으나, 2015년에는 4.0\%, 2016년 3.7\%, 2017년 6.7\%로 증가하 였다.

E. faecium 은 분리균주 대부분이 베타락탐 전반과 linezolid 에 높은 내성률을 보였다(Fig. 4). Quinupristin/dalfopristin과 linezolid에 대한 내성률이 비교적 낮아 각 $10 \%$ 미만의 내성률

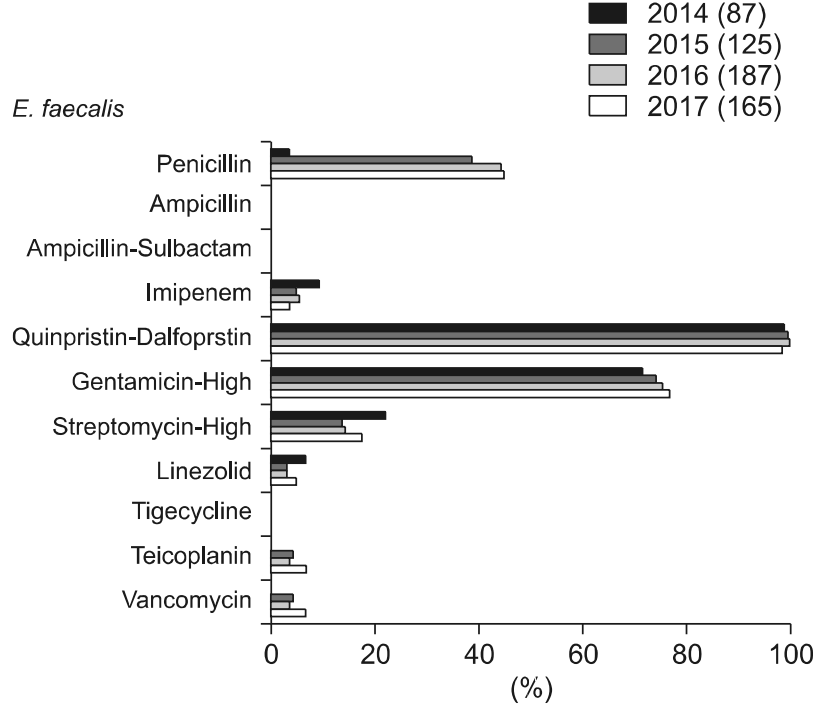

Fig. 4. Resistance rates of $S$. aureus, E. faecalis, and E. faecium in each year. Each bar indicates resistance rate of the year: black bar for 2014, dark gray for 2015, light gray for 2016, and white for 2017. Numbers of isolates analyzed are presented in parentheses following the year in the plot legend.

을 보였고, tigecycline 내성균주는 4년간 한차례도 분리되지 않 았다. 높은 농도의 아미노글라이코사이드에 대한 내성률은 떨 어지고 있는 추세여서, gentamicin-high에 대한 내성률은 2014 년 75.3\%이던 것이 2015년에는 $65.0 \%, 2016$ 년에는 $61.1 \%$, 2017년에는 40.9\%로 줄었고, streptomycin-high에 대한 내성률 은 2014년에 26.0\%에서 2015년에는 27.9\%, 2016년에는 8.4\%, 2017년에는 12.6\%로 줄었다. Vancomycin 내성 E. faecium은 2014년 40.8\%, 2015년 71.4\%, 2016년 48.9\%, 2017년 61.8\%의 발생률을 보였으며 이는 대체로, 인천 지역의 높은 분리율과 높은 내성률이 반영되는 것으로 보였다.

\section{DISCUSSION}

우리나라에서 분리된 임상균주의 내성률이 세계 다른 지역 에 비해 비교적 높은 것으로 알려져 있어 국가적으로 관리와 
감시가 이루어지고 있으나, 비교적 관리가 용이한 종합병원에 집중하고 있는 것이 현실이다. 한편, 고령인구의 비율이 늘어남 에 따라 요양병원의 기관 수가 급격히 늘고 있어서 2017년말 기준, 1,529 개에 달하는 것으로 조사된 바 있다[18]. 급성기와 만성기를 자주 넘나드는, 감염에 취약한 요양병원 환자군의 특 성상 전원이 잦고 입원기간이 길어서 항균제 내성 세균의 전파 에 취약하다는 특성을 가지지만, 병상 수가 천차만별이고 개/ 폐원이 잦기 때문에 내성세균의 분리율을 추적관찰하는 것이 현실적으로 매우 힘들다. 이에, 수탁기관에 의뢰된 항균제 감수 성시험 결과를 분석하는 것이 좋은 방편이라 하겠다.

본 연구에서는 우리나라의 요양병원에서 수집하여 시험수탁 기관으로 항균제 감수성검사가 의뢰된 검체로부터 분리배양한 세균의 항균제 내성 현황을 4년간의 시험결과 분석을 통해 종 합적으로 알아보았다. 요양병원에서 일어나는 세균의 내성전 파 양상이 종합병원에서 일어나는 의료관련감염 내성전파와 유사하다는 사실로 미루어, Kor-GLASS에서 도출된 종합병원 의 의료관련감염(hospital-originated, $\mathrm{HO}$ ) 분리균의 항균제 내 성률과 비교해 보았다. Kor-GLASS는 2016년 5월부터 2017년 4월까지 우리나라 전국의 종합병원에서 분리한 혈액 및 요분리 균주에 대한 분석 결과를 발표한 바 있고[19], Kor-GLASS의 $\mathrm{HO}$ 유래 혈액 분리균의 내성률과 비교할 수 있었다. 2017년의 요양병원 분리균의 내성률과 2016년 5월-2017년 4월의 종합병 원 분리균 내성률을 비교하면, imipenem 내성 A. baumannii를 제외한 나머지에서 요양병원 분리균의 내성률이 높다는 사실 을 확인할 수 있었다. Cefotaxime 내성 K. pneumoniae은 $77.4 \%$ : $50.6 \%$, cefotaxime 내성 E. coli는 70.6\% : 57.1\%, imipenem 내성 A. baumannii 는 90.3\%: 93.4\%, imipenem 내성 P. aeruginosa는 $49.3 \%: 30.0 \%$, 요양병원의 oxacillin 내성 $S$. aureus 와 종합병원의 cefoxitin 내성 S. aureus는 81.1\%: 69.4\%, penicillin 내성 $E$. faecalis 는 44.8\% : 26.7\%, vancomycin 내성 E. faecium은 61.5\% : $54.3 \%$ 의 차이를 보였다. Ampicillin에 감수성이면서 penicillin에 내성인 E. faecalis의 분리율이 높아지는 추세는 종합병원의 감 시에서도 확인된 바 있어, 종합병원 분리주와 마찬가지로 penicillin-binding protein 4 의 변이에 의한 현상일 것으로 추정되었 다[20].

공식적으로 발표된 Kor-GLASS의 결과가 종합병원에 국한 되어 있으나[12], 현재 진행중인 정부 주도의 내성 감시는 종합 병원에서 수집된 균주뿐 아니라 요양병원에서 수집된 세균 균 주에 대한 분석도 포함하고 있으며[21], 추후 발표될 요양병원 의 항균제 내성 감시 결과와 비교하면 보다 흥미있고 객관적인 결과 비교 및 추적이 가능할 것으로 생각한다.

본 연구는 몇가지의 약점을 가지며, 이는 균주 자체에 대한 분석이 아닌 항균제 감수성 시험결과에 대한 수집 분석이 가지 는 한계 때문에 현실적으로 극복이 불가능한 것이었다. 첫째, 4년간 연속적으로 항균제 감수성 시험이 의뢰된 요양병원만을
대상으로 분석하는 것을 원칙으로 하였기 때문에 분석을 실시 한 지역별 요양병원의 숫자가 지역의 인구 수 혹은 노령인구 수를 반영하지 못하여 샘플 사이즈에 차이가 있다. 둘째, 대상 환자에 대한 정보가 불충분하였다. 이 때문에 내성균 반복분리 에 의한 내성률 과장의 가능성을 완전히 배제할 수 없었고, 종 합병원의 항생제 내성 감시 결과와 환자의 연령별 내성률 비교 가 불가능하였다. 셋째, 내성률 자체에 대한 분석에 그치고, 내 성의 원인에 대한 분자적 분석이 결여되어 있다. 균주에 대해 서는 수탁기관에 의뢰된 범위만큼만 시험되었고, 균주 자체를 따로 보관하지 아니하여 추가 연구가 불가능하였다. 넷째, 내성 균의 발생과 그 확산에 대한 분석이 이루어지지 않았다. 일부 요양병원에서 돌연한 내성균 발생이 관찰되었고, 동일 지역으 로 확산되어 가는 것이 확인된 바 있으나, 균주가 보관되어 있 지 않아 이에 대한 자세한 역학적 분석 등을 진행할 수 없었다. 이번 연구를 통해 요양병원에서 분리된 세균의 항균제 내성 률이 종합병원의 내성률보다 높다는 사실을 확인할 수 있었고, 이는 일부 내성균 반복분리에 의한 내성률 과장의 영향도 있겠 으나 항균제 스튜어드십(antimicrobial stewardship)이 미비하고 감염관리에 취약한 요양병원의 현실을 반영하는 것이라 판단 되는 바, 요양병원의 항균제 내성률 감시가 필요하다는 사실에 대한 당위성과 함께 지속적인 감시와 연구를 통한 요양병원에 서의 적절한 항균제 사용과 감염관리의 중요성을 확인할 수 있 었다.

\section{REFERENCES}

1. Founou RC, Founou LL, Essack SY. Clinical and economic impact of antibiotic resistance in developing countries: a systematic review and meta-analysis. PLoS One 2017;12:e0189621.

2. Ryu S. The new Korean action plan for containment of antimicrobial resistance. J Glob Antimicrob Resist 2017;8:70-3.

3. Organization, WH. Global action plan on antimicrobial resistance. Geneva: WHO; 2015.

4. Kim D, Ahn JY, Lee CH, Jang SJ, Lee H, Yong D, et al. Increasing resistance to extended-spectrum cephalosporins, fluoroquinolone, and carbapenem in gram-negative bacilli and the emergence of carbapenem non-susceptibility in Klebsiella pneumoniae: analysis of Korean Antimicrobial Resistance Monitoring System (KARMS) data from 2013 to 2015. Ann Lab Med 2017; 37:231-9.

5. Lee H, Yoon EJ, Kim D, Jeong SH, Shin JH, Shin JH, et al. Establishment of the South Korean national antimicrobial resistance surveillance system, Kor-GLASS, in 2016. Euro Surveill 2018;23.

6. Richards CL Jr and Steele L. Antimicrobial-resistant bacteria in long- term care facilities: infection control considerations. J Am Med Dir Assoc 2003;4(3 Suppl):S110-4.

7. Wiener J, Quinn JP, Bradford PA, Goering RV, Nathan C, Bush $\mathrm{K}$, et al. Multiple antibiotic-resistant Klebsiella and Escherichia coli in nursing homes. JAMA 1999;281:517-23.

8. Lee BY, Bartsch SM, Wong KF, Singh A, Avery TR, Kim DS, et al. The importance of nursing homes in the spread of methi- 
cillin-resistant Staphylococcus aureus (MRSA) among hospitals. Med Care 2013;51:205-15.

9. McBryde ES, Bradley LC, Whitby M, McElwain DL. An investigation of contact transmission of methicillin-resistant Staphylococcus aureus. J Hosp Infect 2004;58:104-8.

10. van den Dool C, Haenen A, Leenstra T, Wallinga J. The role of nursing homes in the spread of antimicrobial resistance over the healthcare network. Infect Control Hosp Epidemiol 2016;37:761-7.

11. VAN Gaalen RD, Hopman HA, Haenen A, VAN DEN Dool C. Staff exchange within and between nursing homes in the Netherlands and potential implications for MRSA transmission. Epidemiol Infect 2017;145:739-45.

12. Jones CD, Cumbler E, Honigman B, Burke RE, Boxer RS, Levy C, et al. Hospital to post-acute care facility transfers: identifying targets for information exchange quality improvement. J Am Med Dir Assoc 2017;18:70-3.

13. Lee SC, Wu MS, Shih HJ, Huang SH, Chiou MJ, See LC, et al. Identification of vancomycin-resistant enterococci clones and inter-hospital spread during an outbreak in Taiwan. BMC Infect Dis 2013;13:163.

14. Donker T, Wallinga J, Slack R, Grundmann H. Hospital networks and the dispersal of hospital-acquired pathogens by patient transfer. PLoS One 2012;7:e35002.

15. Ruiz de Gopegui E, Oliver A, Ramírez A, Gutiérrez O, Andreu C, Pérez JL. Epidemiological relatedness of methicillin-resistant Staphylococcus aureus from a tertiary hospital and a geriatric institution in Spain. Clin Microbiol Infect 2004;10:339-42.
16. Korea Centers for Disease Control and Prevention, Korea Society for Healthcare-associated Infection Control and Prevention. Standard guidelines of the control and prevention for healthcare-associated infections. Sejong: KCDC; 2017 Jul. Report No.: 11-1352159-000840-01. 292 p.

17. Ministry of Health and Welfare. General measures of the control and prevention for health care-associated infections ('18 '22). Sejong: MOHW; 2018 Jun. 34 p.

18. Korean Statistical Information Service (KOSIS). The existing state of hospitals in South Korea by district and by type. http://kosis.kr/ statHtml/statHtml.do?orgId=354\&tblId=DT_MIRE01\&vw_cd=MT ZZTITLE\&list_id $=354 \_M T \_D T I T L E \& s e q N o=\& l a n g \_$mode $=$ko\&la nguage $=$ kor\&obj_var_id $=\& i t m \_i d=\& c o n n \_p a t h=M T \_Z T I T L E$ [Online] (last visited on 1 May 2019)

19. Lee H, Yoon EJ, Kim D, Jeong SH, Won EJ, Shin JH, et al. Antimicrobial resistance of major clinical pathogens in South Korea, May 2016 to April 2017: first one-year report from KorGLASS. Euro Surveill 2018;23.

20. Kim D, Lee H, Yoon EJ, Hong JS, Shin JH, Uh Y, et al. Prospective observational study of the clinical prognoses of patients with bloodstream infections caused by ampicillin-susceptible but penicillin-resistant Enterococcus faecalis. Antimicrob Agents Chemother 2019;63:e00291-19.

21. Ministry of the Interior and Safety. Gugga hangsaengje naeseong gwanlidaechaeg [National Action Plan on Antimicrobial Resistance (2016-2020)]. https://www.gov.kr/portal/gvrnPolicy/view/156146703 [Online] (last visited on 1 May 2019) 
$=$ 국문초록 $=$

\section{4년에서 2017년까지 요양병원에서 분리한 세균의 항균제 내성}

${ }^{1}$ 서울의과학연구소, ${ }^{2}$ 상지대학교 임상병리학과, ${ }^{3}$ 연세대학교 의과대학 진단검사의학교실 및 세균내성연구소 윤선한 $^{1,2}$, 권바름 ${ }^{2,3}$, 홍혜림 ${ }^{1}$, 임환섭 ${ }^{1}$, 이경률 ${ }^{1}$, 장인호 ${ }^{2}$, 윤은정 $^{3}$, 정석훈 $^{3}$

배경: 요양병원의 기관 수가 늘고 있으나, 요양병원 환자에서 분리된 병원균의 항균제 내성률에 대한 감시 결과가 미비 하여 이에 대한 연구가 필요한 바, 국내의 한개 수탁기관에 의뢰된 시험결과를 바탕으로 요양병원의 항균제 내성 현황을 조사하였다.

방법: 2014년 1월부터 2017년 12월까지 4년간, 61 개 요양병원 환자로부터 분리한 총 23,518개 균주의 감수성검사 결과를 분석하였다. VITEK 2 장비를 사용하여 검사하였으며, 균종에 적합한 항균제 감수성 시험 카드를 이용하였다.

결과: 총 19,357주의 그람음성세균과 4,161주의 그람양성세균이 분리되었다. 그람음성세균 중에는 Pseudomonas aerugino$s a(n=6,384)$ 와 Escherichia coli $(n=5,468)$, 그람양성세균 중에는 Staphylococcus aureus $(n=1,565)$ 가 가장 많이 분리된 균종 이었다. 주요 내성세균의 분리비율은 높은 편으로, 2017년 분리균의 cefotaxime 내성률은 Klebsiella pneumoniae에서 77.4\%, E. coli에서 70.6\%였으며, imipenem 내성률은 Acinetobacter baumannii에서 90.3\%, P. aeruginosa에서 49.3\%, oxacillin 내성률로 추정된 S. aureus 의 methicillin 내성률은 $81.1 \%$, Enterococcus faecalis의 penicillin 내성률은 44.8\%, Enterococcus faecium 의 vancomycin 내성률은 $53.5 \%$ 에 달했다. 내성률의 연도별 변화 추이는 균종별, 항균제별로 다양하였다. 결론: 본 연구를 통해 요양병원 환자에서 분리된 세균의 주요 항균제에 대한 내성률이 imipenem 내성 A. baumannii를 제외한 모든 경우에 종합병원에 비해 높음을 확인할 수 있었고, 요양병원의 항균제 내성에 대한 지속적인 감시와 연구를 통한 적절한 항균제 사용과 감염관리의 중요성을 확인할 수 있었다. [Ann Clin Microbiol 2019;22:96-104]

교신저자 : 윤은정, 06273 , 서울시 강남구 언주로 211

연세대학교 의과대학 진단검사의학교실 및 세균내성연구소

Tel: 02-2019-3783, Fax: 02-2019-3784

E-mail: ejyoon@yuhs.ac 